hưởng đến sự co bóp của tim giảm đi và làm giảm cung lượng tim. Các tế bào bị hoại tử sẽ được thay thể bằng những mô xơ, làm giảm đi tính đàn hồi của cơ tâm thất và cuối cùng dẫn đến dẫn đến tim giãn to quámức bình thường. Điều này cũng giải thích tại sao suy tim là dấu hiệu lâm sàng đặc trưng của bệnh cơ tim giãn.

\section{KẾT LUÂNN}

Khi nghiên cứu 34 bệnh nhân bệnh cơ tim giãn được chẩn đoán, điểu trị tại Bệnh viện Nhi Trung ương, kết quả cho thấy các dấu hiệu lâm sàng và cận lâm sàng thường gặp của bệnh cơ tim giãn là suy tim, tim to trên $X$-quang ngực và rối loạn chức năng tâm thu.

\section{TÀI LIÊU THAM KHẢO}

1. Alexander P.M, Daubeney P.E, Nugent A.W, et al (2013). Long-term outcomes of dilated cardiomyopathy diagnosed during childhood: results from a national population-based study of childhood cardiomyopathy. Circulation, 128(18), 2039-2046.
2. Molina K.M, Shrader $P$, Colan S. D, et al (2013). Predictors of disease progression in pediatric dilated cardiomyopathy. Circ Heart Fail,6(6), 1214-1222.

3. Towbin J.A, Lowe A.M, Colan S.D, et al (2006). Incidence, causes, and outcomes of dilated cardiomyopathy in children. JAMA, 296(15), 1867-1876.

4. Đặng Phương Thuý (2017). Giá trịcủa nồng độ NT'-proBNP trong theo dõi bênh cơ tim giãn ởtrẻem. Luận văn tốt nghiệp bác sĩ nội trú, Trướng Đại học Y Hà Nội.

5. Randy Wexler, Terry Elton, Adam Pleister, et al (2009). Cardiomyopathy: An Overview. Am Fam Physician,79(9): 778-784.

6. Susanna B.S, Rizopoulos D, Marchie S.G, et al (2016). Usefulness of Serial N-terminal Pro-Btype Natriuretic Peptide Measurements to Predict Cardiac Death in Acute and Chronic Dilated Cardiomyopathy in Children. Am J Cardiol, 118(11), 1723-1729.

7. Alvarez J.A, Orav E.J, Wilkinson J.D, et al (2011). Competing Risks for Death and Cardiac Transplantation in Children with Dilated Cardiomyopathy: Results from the Pediatric Cardiomyopathy Registry. Circulation, 124(7), 814-823.

\title{
TÌNH TRANG VÙNG QUANH RĂNG, MẤT RĂNG VÀ MộT Số YẾU TỐ LIÊNN QUAN Ở BÊNH NHÂN ĐÁI THÁO ĐƯờNG TÝP 2 TẠI MộT SỐ BỆNH VIỆN Ở HÀ NộI NĂM 2020 - 2021
}

\begin{abstract}
TÓM TẮT
Nghiên cứu được tiến hành trên 156 người bênh đái tháo đường týp 2 tai Bênh viện Nội tiết TW và̀ Bênh viện đa khoa Đống Đa năm 2020-2021 nhằm phân tích mồt số yếu tố liên quan giữa tình trang vùng quanh răng với bệnh đái tháo đường týp 2 ở độ tuổi từ $35-$ 55 . Kết quả cho thấy tỷ lệ bệnh nhân có túi lợ bệnh lý (CPI 3 và 4 ) chiếm $65,4 \%$, tỉ lệ mất răng là $35,9 \%$; HbA1C $\geq 7$ có liên quan mật thiết tới múc độ trầm trong của bệnh quanh răng và ngược lại viêm quanh rẳng cũng là một trong các yếu tố làm bệnh đái tháo đường năng lên. Do vậy cần quan tâm hơn nữa tới vấn đề giáo dục, chăm sóc sức khỏe răng miệng cho đối tượng mắc bệnh đái tháo đường týp 2 đồng thời kết hợp chặt chẽ giửa chuyên khoa nội tiết với răng hàm mặt trong chăm sóc, phát hiện và điều trị kịp thời nhằm duy trì ổn định bệnh quanh răng và hạn chế nguy cơ mất răng ở nhóm đối tượng này là rất cần thiết.
\end{abstract}

${ }^{1}$ Viện Đào tạo Răng Hàm Mặt, Trường Đại học Y Hà Nội ${ }^{2}$ Trường Đại hoc Y Dước - Đại hoc Quốc gia Hà Nội Chịu trách nhiệm chính: Giáp Thị Thuỳ Liên

Email: giapthuylien139@gmail.com

Ngày nhận bài: 14.6.2021

Ngày phản biên khoa hoc: 12.8.2021

Ngày duyệt bài: 23.8.2021
Giáp Thị Thùy Liên', Lê Hưng², Tống Minh Sơn ${ }^{1}$, Lê Long Nghĩa ${ }^{1}$

Từ khóa: Viêm quanh răng, đái tháo đường, CPI, mất răng.

\section{SUMMARY}

PERIODONTAL STATUS, TOOTH LOSS AND RISK FACTORS AMONG TYPE 2 DIABETIC PATIENTS AT HOSPITALS IN HANOI, 2020-2021

The study was conducted on 156 type 2 diabetic patients at National hospital of endocrinology and Dong Da hospital in 2020-2021 to analyze some risk factors between periodontal status and type 2 diabetes of patients aged 35 to 55 . The results show that the rate of periodontal pocket was $65,4 \%$ (CPI3 and CPI4), the incidence of tooth loss was $35,9 \%$. HbA1C level $>7$ was closely related to the severity of periodontal status and periodontal disease also lead to worsening diabetes. Therefore, it is necessary to pay more attention to dental health care for type 2 diabetic patients. Besides, the combination of endocrinology with odonto-stomatology in timely diagnosis and treatment in this subject is essential in order to control periodontal disease and limit the risk of tooth loss.

Keywords. periodontitis, diabetes, CPI, tooth loss

\section{I. ĐẶT VẤN ĐỀ}

Những năm gần đây ở nước ta, cùng với sự 
phát triển của kinh tế xã hôi thì nhu câu chăm sóc sức khoẻ nói chung và sức khoẻ răng miệng nói riêng ngày càng được người dân quan tâm. Bên cạnh đó, sự bùng nổ và gia tăng nhanh chóng của bệnh đái tháo đường và các biến chứng của chúng là gánh nặng lớn đối với các nước đang phát triển trong đó có Việt Nam. Do đó, những nghiên cứu về đái tháo đường và mối liên quan của đái tháo đường với các bệnh lý khác luôn là mối quan tâm của $Y$ học và cộng đồng, trong đó nhiêu nhà nghiên cứu đã đi đến kết luận đái tháo đường týp 2 là một yếu tố nguy cơ của bệnh quanh răng ${ }^{5,6}$.

Trên thế giới nói chung và tại Việt Nam nói riêng đã có nhiều công trình nghiên cứu về mối tương quan hai chiều giữa bệnh quanh răng và đái tháo đường týp 2 , tuy nhiên ngày nay tỷ lệ người mắc đái tháo đường týp 2 đang có $x u$ hướng trẻ hoá trong khi đó những nghiên cứu đánh giá về ảnh hưởng của nó đối với sức khoẻ vùng quanh răng và nhu cầu điều trị bệnh răng miệng của các đối tượng ở độ tuổi 35-55 còn hạn chế. Xuất phát từ tình hình thực tế trên, chúng tôi tiến hành nghiên cứu đề tài: "Tình trạng vùng quanh răng, mât răng và một số yêu tố liên quan ở bệnh nhân đái tháo đường týp 2 tai môt số bệnh viện ở Hà Nội năm 2020 - 2021" với muc tiêu:

Mồ tả tình trạng vùng quanh răng, mất răng và một số yêu tố liên quan ở người bệnh đái tháo đường týp 2 tại một số bệnh viện ở Hà Nội năm 2020 - 2021.

\section{II. ĐỐI TƯỢNG VÀ PHƯƠNG PHÁP NGHIÊN CỨU}

2.1 Đối tượng nghiên cứu. Nghiên cứu được tiến hành từ tháng 07 năm 2020 đến tháng 07 năm 2021 trên 156 bệnh nhân được chẩn đoán mắc đái tháo đường týp 2 theo tiêu chuẩn của ADA $2020^{3}$ tại 2 địa điểm là phòng Răng Hàm Mặt - Khoa Liên khoa, Bệnh viện Nội tiết Trung ương và khoa Khám bệnh Bệnh viện đa khoa Đống Đa.

- Tiêu chuẩn lứa chọn là bệnh nhân có độ tuổi từ $35-55$, có ít nhất một vùng lục phân còn chức năng, tại thời điểm nghiên cứu không mắc các bệnh cấp tính khác và bệnh nhân tự nguyện tham gia nghiên cứu.

- Tiêu chuẩn loại trừ: Bênh nhân không hợp tác khi tiến hành nghiên cứu và bệnh nhân mất răng toàn bộ.

\subsection{Phương pháp nghiên cứu}

- Thiết kế nghiên cứu: nghiên cứu mô tả cắt ngang

- Cõ̃ mẫu: Áp dung công thức cho nghiên cứu mô tả cắt ngang ước lượng một tỷ lệ:
Trong đó: n: cõ̃ mẫu

$$
\boldsymbol{n}=\frac{z_{\left(1-\alpha_{/ 2)}\right.}^{2} p(1-p)}{d^{2}}
$$

a: mức ý nghĩa thống kê, chọn $a=0,1$

p: tỉ lệ mắc bệnh quanh răng ở bệnh nhân đái tháo đường, theo nghiên cứu của N.S. Rajhans và cộng sự: $p=0,868^{7}$.

d: sai số cho phép, chọn $\mathrm{d}=0,05$.

Thay vào tính được cỡ mẫu cần có $\mathrm{n}=124$ thực tế chúng tôi tiến hành nghiên cứu trên 156 bệnh nhân.

\subsection{Các bước tiến hành nghiên cứu}

2.3.1. Dung cụ thu thâp số liệu

- Bộ phiếu điều tra, bút ghi, phiếu khám

- Bổ khay khám nha khoa

- Gel nhuộm mảng bám GC Tri Plaque ID gel.

- Cây thằm dò nha chu Apex Dental USA UNC15 1105

2.3.2. Phương pháp thu thập số liệu

- Phỏng vấn bệnh nhân để thu thập các thông tin chung.

- Đối tượng được khám đánh giá và ghi nhận các thông tin về lầm sàng mô lợi, chỉ số lợi GI, chỉ số mảng bám PI và chỉ số nhu cầu điều trị quanh răng của cộng đồng CPITN, khám xác định răng mất, phẩn loại mất răng và chỉ định nhu câu phục hình.

- Đối tượng được tư vấn và hướng dẫn chăm sóc răng miệng.

2.4. Xử lý số liệu. Nhập dữ liệu bằng phần mềm Epi-data. Xử lý, phẩn tích số liệu bằng phần mềm SPSS 20.0 và một số thuật toán thống kê y học khác.

\subsection{Biện pháp hạn chế sai số}

- Đối tượng nghiên cứu được chọn theo đúng tiêu chuẩn.

- Phiếu khám được xây dựng theo mục tiêu, dễ thu thập thông tin.

- Nhập số liệu và xử lý số liệu được tiến hành hai lần để đối chiếu kết quả.

2.6. Đạo đức trong nghiên cứu. Nghiên cứu chỉ tiển hành khi được sự đồng ý của Ban lãnh đạo Bệnh viện Nội tiết Trung ương và Bệnh viện đa khoa Đống Đa. Mọi thông tin liên quan đển đối tượng nghiên cứu được giữ bí mật. Đối tượng tham gia nghiên cứu hoàn toàn tự nguyện. Quá trình khám đảm bảo vô khuẩn, phòng chống lây nhiễm chéo. Tất cả các đối tượng tham gia nghiên cứu đều được tư vấn vệ sinh răng miệng.

\section{KẾT QUẢ NGHIÊN CỨU}

Qua nghiên cứu 156 bệnh nhân mắc đái tháo đường týp 2 tại 2 bệnh viện chúng tôi thu được 
một số kết quả như sau:

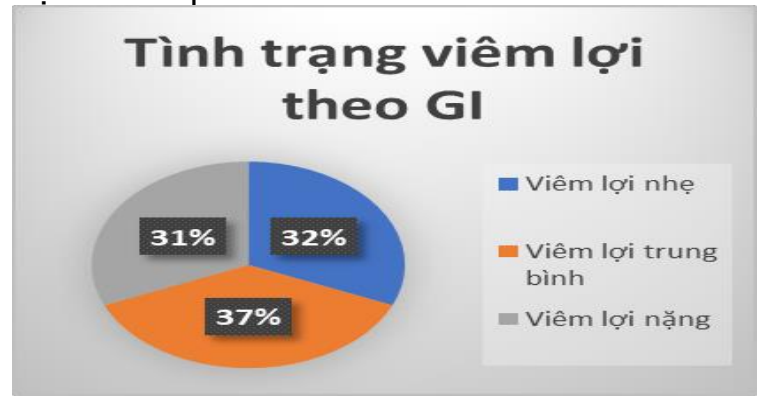

Tình trạng quanh răng theo CPITN $0 \quad 11$

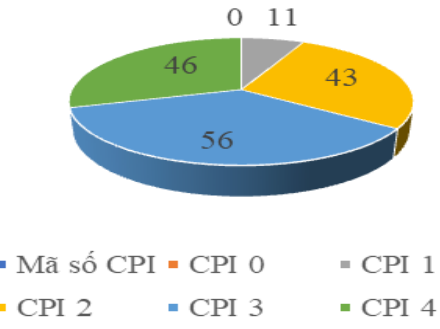

Biểu đồ 1. Tình trạng viêm lợi và vùng quanh rang

Nhận xét: Không có tỷ lệ lợi hoàn toàn khoẻ mạnh. Các mức độ viêm lợi có tỉ lệ tương đương nhau, trong đó viêm lợi nặng chiếm tỷ lệ khá cao với 31,4\%. Trung bình chỉ số GI là: 1,56 $\pm 0,75$. Tỷ lệ bênh nhân có túi lợi bênh lý (CPI 3 và 4 ) chiếm tới $65,4 \%$, trong đó số bệnh nhân có túi sâu (CPI 4) chiếm 29,5\%.

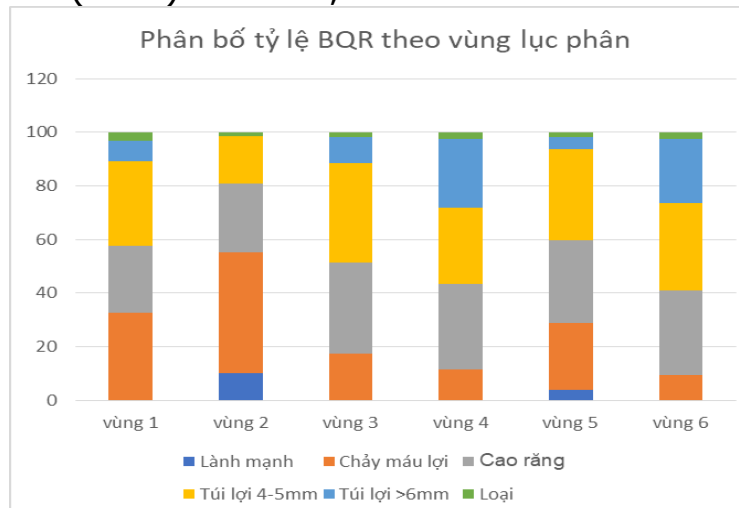

Biểu đồ 2. Phân bố tỷ lệ bệnh quanh răng theo vùng lục phân

Nhận xét: Vùng 2 và vùng 5 có tình trạng quanh răng ít trâm trọng hơn so với các vùng còn lại. Tỷ lệ có túi lợi bệnh lý sâu (CPI 4) thấp nhất ở vùng 2 , ngược lại tỷ lệ này cao nhất ở vùng 4.

Bảng 1. Tỷ lệ các loại mât răng theo Kenedy-Applegate

\begin{tabular}{|c|c|c|c|c|c|c|}
\hline \multirow[b]{2}{*}{ Phân loại } & \multicolumn{2}{|c|}{ Hàm trên } & \multicolumn{2}{|c|}{ Hàm dưới } & \multicolumn{2}{|c|}{ Tổng số BN mất răng } \\
\hline & $\begin{array}{c}\text { Số lượng } \\
\text { BN mất } \\
\text { răng }\end{array}$ & $\begin{array}{l}\text { Tỷ lề } \\
\text { (\%) }\end{array}$ & $\begin{array}{c}\text { Số lượng } \\
\text { BN mất } \\
\text { răng }\end{array}$ & $\begin{array}{l}\text { Tỷ lệ } \\
\text { (\%) }\end{array}$ & $\begin{array}{c}\text { Số lượng } \\
\text { BN mất } \\
\text { răng }\end{array}$ & $\begin{array}{l}\text { Tỷ lề } \\
(\%)\end{array}$ \\
\hline Loại I, II & 19 & 12,2 & 25 & 16 & \multirow{3}{*}{56} & \multirow{3}{*}{35,9} \\
\hline Loai III, IV, V & 7 & 4,5 & 2 & 1,3 & & \\
\hline Loại VI & 30 & 19,2 & 29 & 18,6 & & \\
\hline Không mất răng & 100 & 64,1 & 100 & 64,1 & 100 & 64,1 \\
\hline Tống số BN nghiên cứu & 156 & 100 & 156 & 100 & 156 & 100 \\
\hline
\end{tabular}

Nhận xét: Trong nghiên cứu được thực hiện tỉ lệ mất răng ở các đối tượng là 56/156 bệnh nhân chiếm $35,9 \%$, tỉ lệ không mất răng cao hơn là $64,1 \%$. Trong các phân loại mất răng theo Kenedy Applegate, tỉ lệ mất răng loại VI là cao nhất, tức là mất răng đơn lẻ chiếm 19,2\% hàm trên và 18,6 $\%$ hàm dưới.

Bảng 2. Tình trạng quanh răng theo HbA1C

\begin{tabular}{|c|c|c|c|c|c|c|}
\hline \multirow{2}{*}{$\begin{array}{c}\text { HbA1c } \\
(\%)\end{array}$} & \multicolumn{2}{|c|}{ CPI 2} & \multicolumn{2}{|c|}{ CPI 3 và CPI 4} & \multirow[b]{2}{*}{ OR } & \multirow{2}{*}{$95 \% \mathrm{CI}$} \\
\hline & Số lương & Tỷ lệ (\%) & Số lương & Tỷ lệ (\%) & & \\
\hline$<7$ & 44 & 69,8 & 19 & 30,2 & 19,2 & $8,23-44,90$ \\
\hline$\geq 7$ & 10 & 10,8 & 83 & 89,2 & 15,2 & $0,20-44,50$ \\
\hline
\end{tabular}

Nhân xét: Tỷ lệ CPI 3 và CPI 4 ở nhóm HbA1c kiểm soát kém cao hơn nhiêu ở nhóm HbA1c kiểm soát tốt, khác biệt giữa 2 nhóm là có ý nghĩa thống kê $p=0,000$. Nhóm người kiểm soát HbA1c kém nguy cơ có túi lợi bệnh lý nặng cao gấp 19,2 lần nhóm kiểm soát tốt (95\%CI: 8,23-44,90).

Bảng 3. Tình trạng quanh răng theo mức thu nhập trung bình/tháng

\begin{tabular}{|c|c|c|c|c|c|c|}
\hline \multirow{2}{*}{$\begin{array}{l}\text { Mức thu nhập } \\
\text { TB/tháng } \\
\text { (triệu/tháng) }\end{array}$} & \multicolumn{2}{|c|}{ CPI $\leq 2$} & \multicolumn{2}{|c|}{ CPI 3 và CPI 4} & \multirow[b]{2}{*}{ OR } & \multirow[b]{2}{*}{$95 \%$ CI } \\
\hline & Số lượng & $\begin{array}{l}\text { Tỷ lệ } \\
(\%)\end{array}$ & Số lượng & $\begin{array}{l}\text { Tỷ lêê } \\
\text { (\%) }\end{array}$ & & \\
\hline$<4,23^{*}$ & 9 & 13,2 & 59 & 86,8 & 6,9 & $3,03-15,52$ \\
\hline$\geq 4,23 *$ & 45 & 51,1 & 43 & 48,9 & & \\
\hline
\end{tabular}


(*: thu nhập bình quân đầu người/tháng của Việt Nam năm 2020 được tính toán dựa trên cơ sở cuộc khảo sát mức sống dân cư, hộ gia đình do Tổng cục thống kê điều tra định kì 2 năm/lần)

Nhận xét: Tỷ lệ CPI 3 và CPI 4 ở nhóm có thu nhập trung bình/ tháng thấp chiếm tỷ lệ cao hơn ở nhóm người thu nhập trung bình/tháng cao, khác biệt giữa 2 nhóm là có ý nghĩa thống kê $p=0,000$. Nhóm có thu nhập trung bình/tháng thấp có nguy cơ túi lợi bệnh lý nặng cao gấp 6,9 lần nhóm có thu nhập trung bình/tháng cao (95\%CI: 3,03-15,52).

\section{BÀN LUÂN}

Trong nghiên cứu này chúng tôi khu trú ở đối tượng có độ tuổi trẻ hơn với khoảng tuổi ngắn hơn 35-55 tuổi. Sở dĩ nghiên cứu của chúng tôi lựa chọn khu trú đối tượng trẻ là do ngày nay độ tuổi mắc đái tháo đường týp 2 ngày càng trẻ hóa trong khi những nghiên cứu về ảnh hưởng của đái tháo đường týp 2 với tình trạng răng miệng ở nhóm đối tướng này chưa nhiều. Ngoài ra hiện nay $\mathrm{HbA1c}$ vẩn được coi là "tiêu chuẩn vàng" ${ }^{11}$ trong theo dõi đánh giá mức độ kiểm soát glucose máu ở người bệnh đái tháo đường. Do vậy, chúng tôi thấy sử dụng chỉ số HbA1c để đánh giá mức độ kiểm soát glucose máu sẽ khách quan và chính xác hơn.

Kết quả nghiên cứu biểu đồ 1 cho thấy tỉ lệ CPI 3 và CPI 4 khá cao, lên đến $65,4 \%$. Thực tế cho thây tình trạng quanh răng ở bệnh nhân đái tháo đường týp 2 đa phần nặng hơn ở những người không mắc đái tháo đường. Nhận định này cũng phù hợp với kết luận của tác giả khác như Campus $\mathrm{G}$ và cộng sự Italy $-2005^{4}$. Khi so sánh thực trạng bệnh quanh răng với nghiên cứu khác có cùng đối tượng là các bệnh nhân đái tháo đường cho thấy kết quả nghiên cứu của chúng tôi tương đồng với nghiên cứu của Nguyễn Xuân Thực 2011 với tỉ lệ CPI3 và 4 là $76 \%{ }^{2}$.

Trong nghiên cứu chúng tôi thực hiện, tỉ lệ mất răng ở các đối tượng là 56/156 bệnh nhân (chiếm 35,9\%), tỉ lệ không mất răng là $64,1 \%$. Tỉ lệ mất răng ở mức trung bình có thể lý giải là do nghiên cứu của chúng tôi tập trung vào nhóm bệnh nhân có độ tuổi trẻ hơn ( 35 - 55 tuổi), tình trạng răng miệng chưa chịu tác động quá lớn của tuổi tác, hơn nữa họ đều trong độ tuổi lao động có thu nhập, nên có khả năng tiếp cận để điều trị các bệnh răng miệng dẫn đến tỉ lệ mất răng ít hơn. Điêuu này cũng lý giải phần nào trong nghiên cứu đa phần bệnh nhân mất răng loại VI (theo phân loại mất răng của Kenedy Applegate) tức là mất răng đơn lẻ chiếm 19,2\% đối với hàm trên và 18,6 \% đối với hàm dưới, sau đó là mất răng hàm một hoặc 2 bên. Không có trường hợp mất răng toàn hàm nào được ghi nhận. Tuy nhiên muốn khảo sát chính xác hơn về tình trạng mất răng có lẽ chúng tôi cần phải thực hiện với quy mô cỡ mẫu lớn hơn.

Khi xem xét một số yễu tố liên quan ta có thể thây ảnh hưởng rõ của tuổi tác, mức thu nhập trung bình/tháng và nồng độ $\mathrm{HbA} 1 \mathrm{C}$ lên bệnh quanh răng và mất răng. Để giải thích hiện tượng trên, chúng tôi cho rằng tuổi tác ảnh hưởng đến bệnh quanh răng là do có sự tích luỹ bệnh theo thời gian của đời người, có sự giảm sinh tế bào sợi, giảm tổng hợp collagen, sự lão hoá của tổ chức quanh răng... dẫn đến tình trạng dễ mắc các bệnh răng miệng hơn. Tuổi càng cao thì càng chịu nhiều tác động bất lợi đối với sức khoẻ quanh răng. Bởi vậy chúng ta cần có thái độ quan tâm hơn đối với bệnh quanh răng. Bên cạnh đó, bảng 3 cũng chỉ ra nhóm người thu nhập trung bình/tháng thấp nguy cơ có túi lợi bệnh lý nặng cao gấp 6,9 lần nhóm có thu nhập trung bình/tháng cao. Trong nghiên cứu này chúng tôi dựa trên mức thu nhập bình quân đâuu người năm 2020 ở Việt Nam là 4,23 triệu VNĐ/tháng để chia thành 2 nhóm khảo sát là nhóm thu nhập trung bình/tháng cao và thấp hơn so với mức thu nhập bình quân đầu người chung của cả nước. Qua đó có thể thấy rõ mức thu nhập trung bình/tháng của đối tượng trong nghiên cứu có ảnh hưởng không hề nhỏ đến vấn đề sức khỏe răng miệng nói chung và bệnh quanh răng nói riêng. Điều này có thể lý giải do những người có mức thu nhập trung bình/ tháng thấp hơn so với mức thu nhập bình quân đầu người của cả nước tức là mức sống của họ sẽ được xếp vào loại thấp so với mặt bằng chung của xã hội. Vì thế mức chi tiêu đối với việc chăm sóc sức khoẻ nói chung và sức khoẻ răng miệng nói riêng sẽ bị giới hạn, khả năng được tiếp cận với các dịch vụ y tế, các kỹ thuật mới trong chuẩn đoán và điều trị bệnh đái tháo đường rất hạn chế, hơn nữa bản thân những lao động này cũ̉ng chưa có ý thức chăm sóc răng miểng tốt, chưa hiểu được tầm quan trọng của sức khoẻ răng miệng cũng như việc thăm khám để phòng tránh sớm những nguy cơ, biến chứng có thể xảy ra khi mắc đái tháo đường. Do đó mục đích dự phòng và điều trị cuối cùng vẫn là khống chế, giảm thiểu những biến chứng và những hệ quả mà bệnh quanh răng gây ra, cắt đứt các mắt xích bệnh lý liên quan, từng bước cải thiện sức khoẻ răng miệng, nâng cao chất lượng sông cho người bệnh đặc biệt là các bệnh nhân đái tháo 
đường týp 2. Trên thực tế, đái tháo đường týp 2 thường không được phát hiện sớm và điều trị kịp thời, nhiều trường hợp bệnh chỉ được phát hiện ở giai đoạn muộn khi đã có nhiều biến chứng. Có những bệnh nhân phát hiện sớm nhưng kiểm soát không tốt và ngược lại. Do đó chính việc điều trị đái tháo đường mà cụ thể hơn là việc kiểm soát glucose máu mới là một yếu tố quan trọng có ảnh hưởng đến bệnh quanh răng ở đối tượng nghiên cứu, và vì thế việc xem xét ảnh hưởng của $\mathrm{HbA1c}$ là tối quan trọng. Kết quả nghiên cứu một lần nữa khẳng định kiểm soát glucose máu có liên quan mật thiết với bệnh quanh răng. Bảng 2 chỉ ra tỷ lệ túi lợi bệnh lý CPI 3 và CPI 4 ở nhóm HbA1c kiểm soát kém cao hơn nhiều ở nhóm HbA1c kiểm soát tốt, khác biệt giữa 2 nhóm là có ý nghĩa thống kê $p=0,000$. Đồng thời nhóm người kiểm soát HbA1c kém có nguy cơ túi lợi bệnh lý nặng cao gấp 19,2 lần nhóm kiểm soát tốt $(95 \%$ CI: 8,2344,90). Trong nghiên cứu của mình, Tervonen và Oliver cũng đã kết luận: những người đái tháo đường kiểm soát glucose máu kém sau 2-5 năm có tỷ lệ túi quanh răng lớn hơn đáng kể so với nhóm kiểm soát glucose máu tốt ${ }^{8}$.

\section{KẾT LUẬN}

Tỷ lể bệnh nhân có túi lợi bênh lý (CPI 3 và 4) chiếm $65,4 \%$, tỉ lệ mất răng là $35,9 \%$ trong đó phần lớn là mất rắng loại VI tức là mất răng đơn lẻ (theo phân loại của Kenedy - Applegate) chiếm 19,2\% ở hàm trên và $18,6 \%$ ở hàm dưới.
Nhóm kiểm soát HbA1c kém có nguy cơ mắc viêm lợi nặng cao gấp 19,6 lần, nguy cơ túi lợi bệnh lý nặng cao gấp 19,2 lần so với nhóm kiểm soát HbA1c tốt. Ngoài ra nhóm bênh nhân có thu nhập trung bình/ tháng thấp có tỷ lệ CPI 3, CPI 4 chiếm tới $86,8 \%$ và nguy cơ có túi lợi bệnh lý nặng cao gấp 6,9 lần so với nhóm bệnh nhân có thu nhập trung bình/ tháng cao.

\section{TÀI LIÊU THAM KHẢO}

1. Bình Ta Văn. Bênh đái tháo đường - tăng glucose máu. Nhà xuất bản Y học; 2006. 24-36 p.

2. Thực Nguyễn Xuân. Nghiên cứu bênh quanh răng ở bệnh nhân đái tháo đường týp 2 tại Bệnh viên Nội tiết Trung ương và đánh giá hiệu quả can thiêp [İnternet]. 2011 [cited 2021 Aug 21].

3. ADA. Standards of Medical Care in Diabetes2020. Diabetes Care. 2020 Jan 1;43 (Supplement 1): S14-31.

4. Campus G, Salem A, Uzzau S, Baldoni E, Tonolo G. Diabetes and periodontal disease: a case-control study. J Periodontol. 2005 Mar;76(3):418-425.

5. Genco RJ. Current view of risk factors for periodontal diseases. J Periodontol. 1996 Oct; 67(10 Suppl):1041-1049.

6. Grossi SG, Genco RJ, Machtei EE, Ho AW, Koch G, Dunford R, et al. Assessment of risk for periodontal disease. II. Risk indicators for alveolar bone loss. J Periodontol. 1995 Jan;66(1):23-29.

7. Rajhans NS, Kohad RM, Chaudhari VG, Mhaske NH. A clinical study of the relationship between diabetes mellitus and periodontal disease. J Indian Soc Periodontol. 2011 Oct;15(4):388-392.

8. Tervonen $\mathbf{T}$, Oliver $\mathbf{R C}$. Long-term control of diabetes mellitus and periodontitis. J Clin Periodontol. 1993 Jul;20(6):431-435.

\title{
ĐĂC ĐIỂM LÂM SÀNG, CÂN LÂM SÀNG BÊ̂NH VIỂM NÃO KHÁNG THỤ THỂ NMDA Ở TRẺ EM
}

\author{
Nguyễn Thị Bích Vân ${ }^{1}$, Cao Vũ Hùng1, Nguyễn Thị Thu Hiền ${ }^{1}$,
} Nguyễn Thị Hương ${ }^{1}$, Nguyễn Thị Mây ${ }^{1}$

\section{TÓM TẮT}

Mục tiêu: Mô tả đặc điểm lâm sàng, cận lâm sàng bệnh viêm não kháng thụ thể NMDA ở trẻ em. Phương pháp: Mô tả cắt ngang 61 bệnh nhân được chẩn đoán viêm não kháng thụ thể NMDA, thời gian từ tháng $1 / 2019$ đến tháng 8/2021 tại bệnh viện Nhi Trung ương. Kết quả: Có 25 trẻ nam, 36 trẻ nữ, tuổi trung bình $7,0 \pm 3,7 ; 50,8 \%$ có triệu chứng tiền triệu 1-2 tuần trước khi bị bệnh; 45,9\% số bệnh nhân bị co

${ }^{1}$ Bệnh viện Nhi Trung ương

Chịu trách nhiệm chính: Nguyễn Thị Bích Vân

Email: nguyenbichvan1984@gmail.com

Ngày nhận bài: 15.6.2021

Ngày phản biên khoa hoc: 12.8.2021

Ngày duyệt bài: 17.8.2021 giật khi khởi phát bệnh. Triệu chứng từ khi khởi phát đển thời điểm chẩn đoán: rối loan hành vi $93,4 \%$; rối loạn cảm xúc 68,9\%; rối loạn giấc ngủ 75,4\%; rối loạn vần đông $52,5 \%$; rối loạn ngôn ngữ 47,5\%; suy giảm trì giác $77 \%$. Bất thường hoạt động nền trên điện não đồ dang sóng chậm toàn thể hoắc khu trú $93,5 \%$; sóng kịch phát dạng động kinh 23,9\%; bất thường tín hiêu trên công hưởng từ sọ não $24,6 \% ; 70,0 \%$ có biến đổi dịch não tủy tăng protein hoặc tăng bạch câu. Kết luân: Bênh viêm não kháng thư thể NMDA ở trẻ em có triệu chứng lâm sàng đa dạng, co giật là triệu chứng khởi phát hay gặp, nổi bật là các biểu hiện rối loạn hành vi - cảm xúc, rối loạn giấc ngủ, suy giảm tri giác và rối loạn vận động. Vể cận lâm sàng hay gặp nhất là biến đổi trên điện não đồ với hoạt động sóng chậm và thay đổi dịch não tủy, cộng hưởng từng sọ não thay đổi ở $1 / 4$ số trường hợp. 